\title{
The Influence of Branding Management on Business Performance: An Empirical Evidence from Vietnamese Food and Beverage Industry
}

\author{
Pham Thi Thanh Hong ${ }^{1} \&$ Dinh Kim Quynh Diep ${ }^{1}$ \\ ${ }^{1}$ Hanoi University of Science and Technology, Vietnam \\ Correspondence: Pham Thi Thanh Hong, Hanoi University of Science and Technology, Vietnam.
}

Received: March 27, 2016

Accepted: April 14, 2016

Online Published: April 22, 2016

doi:10.5430/ijba.v7n3p36

URL: http://dx.doi.org/10.5430/ijba.v7n3p36

\begin{abstract}
This study examined the relationship between branding and firm's financial performance within Vietnamese small and medium-sized enterprises (SMEs) in food and beverage industry. Analyzing data from 135 Vietnamese SMEs, the study provided an evidence for the positive relationship between branding management and business performance. The study also provided a deep insight on how Vietnamese entrepreneurs think and develop their brands; therefore, made some recommendations for businessmen, policy makers and branding service providers in Vietnam.
\end{abstract}

Keywords: brand orientation, brand identity, internal branding, brand performance, SMEs, Vietnam

\section{Introduction}

Traditionally, branding is for large company's issue, and rarely considered as a SME's issue (Ahonen, 2008). Although it is well-known that branding is important and takes effects on firm's performance (Keller, 2003), SMEs are quite difficult in making decision of investing their brand formally. Most of them are not fully aware of the importance of branding while others face the limited financial and human resources, or lack of branding know-how, or the like. For SMEs, branding is often considered as a luxury, not an investment. However, SMEs are obviously branding in some extent in order to maintain their business. As branding requires long-term strategy, adequate efforts and resources, SME's owners or managers are reluctant to start or pursue branding activities even if they are quite interested in changing and better marketing practices (Lukoma \& Nguyen, 2011).

According to some researchers, barriers that block SMEs to branding include the lack of knowledge, resources shortage, and insufficient branding guidance for entrepreneurs (Juntunen et al., 2010). This also seems similar to the case of Vietnamese SMEs. Unofficial reports in Vietnam showed some facts on weak branding practice in Vietnamese firms; such as most firms do not put enough efforts in branding; or most of the firms do not have a department or a person in charge of branding. Some do not have any branding strategy, while as some have not registered their logos or brand name, and the like. However, these reports merely emphasized on the issues of branding, not the impacts of branding on company's performance. Therefore, the study is aiming to figure out evidences of the branding's impacts on financial performance, and then encourages SMEs in branding more aggressively and effectively.

In details, this study aims to (1) discover actual branding in Vietnamese food and beverage's SMEs via brand orientation, brand identity development, internal branding, and brand performance; (2) figure out evidences on impacts of branding strategy on brand performance, and thus, financial performance; and (3) get managerial implications on branding to get better brand performance and financial performance.

\section{Research Designs}

\subsection{Hypothesis}

According to Keller (2009), the perception of firm's owners/managers in branding is critical because a strong brand is a powerful instrument to achieve numerous marketing goals, such as improving perceptions on product; getting customer loyalty; reducing vulnerability due to competitive marketing and marketing crises; raising margins; getting more elastic demand toward price decreases and less elastic demand to price increases; improving trading, improving 
cooperation and support from intermediaries; increasing effectiveness of marketing communication; and increasing opportunities of additional licensing and brand extending. Keller (2009) also stated that the ability to realize those benefits depends on the marketing skills of firms' owners/managers as well as firm's resources, market situations, and contexts. Thus, brand orientation clearly has impacts on brand performance, then should be considered as the first component affecting on firm's performance and growth.

Brand orientation refers to firms with broader understanding of the significance of branding to the whole organization and its business operations. Being brand-oriented, firms then use integrated marketing communication to push brand related performance, such as brand awareness, loyal customers, a positive image, and good reputation. Hence, brand orientation contributes greatly to the development of brands as well as brand performance and business performance (Ewing and Napoli, 2005). Empirical evidences have proven the positive relationship between brand orientation and brand performance (Wong \& Merrilees, 2008). Thus, a hypothesis is proposed as follow:

H1: Brand orientation is positively related to brand performance.

Attitudes toward branding or a brand-oriented mindset cannot itself lead to firm's success without proper implementation (Wong \& Merrilees, 2005). Brand-oriented firms should engage with the development of their brand identity (Reid, Luxton \& Mavondo, 2005). Brand identity development begins with defining brand vision and brand values (Keller, 2003). All visual symbolism of the brand should promote the intangible aspects of the brand identity in the process of brand communication. Brand identity components, both tangible and intangible are the key to success of the brand. The position of the brand will be strengthening in customer's perception only when brand communication efforts are consistent. Hence:

\section{H2: Brand identity development is positively related to brand performance.}

Internal branding is the overall efforts to communicate and educate employees on the brand message (Aurand, Gorchels \& Bishop, 2005; Jagdish and Mona, 2015). The solely factor that makes a firm distinctive to their competitors in long-term is service by their employee, not the product features which are easy to be copied. However, poor service also distinguishes firms with each other. Companies should ensure that their employees deliver a coherent brand messages through both oral communication and behaviors (e.g. Henkel et al., 2007; King \& Grace, 2006). Firms should disseminate the brand message to all employees, to make them firstly be aware of the brand and then act in a proper manner that support the brand promise (Papasolomou \& Vrontis, 2006). Brand identity development is useless without the employee's behaviors that actualize it (Aurand, Gorchels \& Bishop, 2005). Internal branding do not restrict to educating employees only but cover employee recruitment also (King \& Grace, 2006). The success of a brand results from employees and their behaviors in their service delivery (de Chernatony and Segal-Horn, 2003; Jagdish and Mona, 2015). Thus:

\section{H3: Internal branding is positively related to brand performance.}

"Brand performance is a prerequisite for financial performance" (Hirnoven and Laukkanen, 2011). Kim et al (2003) also examined and proved the positive effects of brand loyalty, brand awareness and brand image on financial performance. As a consequence, a hypothesis is proposed as followed:

\section{H4: Better brand performance is associated with more satisfied financial performance.}

\subsection{Data Collection}

There are about 11,700 F\&B enterprises in Vietnam including about 5,000 food processing enterprises, 4,000 F\&B service providers and 1,700 beverage manufacturers in Vietnam. They account for $1.7 \%$ out of the total number of operating firms in Vietnam. Almost F\&B firms in Vietnam are private SMEs. The ratio of state-owned enterprises in this industry is only $2.8 \%$, and FDI enterprises accounts for only $6.5 \%$. The number of small and micro enterprises in food and beverage sector is about $89.6 \%$ (Note 1). The author conducted the survey by sending questionnaire to 1,570 food and beverage SMEs of 4 groups: (1) Processing and packaging enterprises (460 questionnaires); (2) Manufacturers (508 questionnaires); (3) Distributors (234 questionnaires); and (4) Suppliers and service providers (368 questionnaires). Most of these enterprises are located in Hanoi and Hochiminh City (approximately 85.03\%). The others are from Bien Hoa, Binh Duong, Can Tho, Da Nang, Dong Nai, Dong Thap, Hai Phong, Hoa Binh, Hue, Khanh Hoa, Lam Dong, Phu Yen, Quang Ninh, Vung Tau, Thai Binh, etc.

In return, there are 167 respondents. 135 out of them are qualified to be analyzed. 
Table 1. Respondents' descriptions

\begin{tabular}{clcc}
\hline Characteristics & Items & Percentages & Numbers \\
\hline Location & Hanoi & 38.52 & 52 \\
\hline & Hochiminh City & 54.81 & 74 \\
\hline & Others & 6.67 & 9 \\
\hline Company Size & Micro & 26.67 & 36 \\
\hline & Small & 42.22 & 57 \\
\hline & Medium & 31.11 & 42 \\
\hline Type of business & State-owned & 13.33 & 18 \\
\hline & Private & 57.78 & 78 \\
\hline & Others & 28.89 & 39 \\
\hline
\end{tabular}

\subsection{Reliability Test}

The reliability of the subscales was tested for their inter-item consistency. The below table presents the results of reliability analysis for brand orientation, brand identity development, internal branding, brand performance and financial performance respectively.

Table 2. Results of Reliability Analysis

\begin{tabular}{|c|c|c|c|c|}
\hline Components & Items & $\begin{array}{c}\text { Corrected } \\
\text { Items - Total } \\
\text { Correlation }\end{array}$ & $\begin{array}{l}\text { Cronbach's } \\
\text { Alpha if Item } \\
\text { deleted }\end{array}$ & Comment \\
\hline \multirow{9}{*}{ 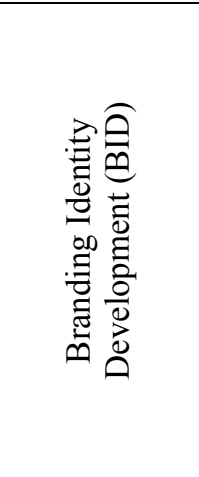 } & We have differentiated our brand from the competitors & .327 & .814 & Deleted \\
\hline & We focus to build personality for our brand & .190 & .831 & Deleted \\
\hline & We know where we are heading to the future & .620 & .772 & \\
\hline & $\begin{array}{l}\text { We know what need to be done to reach our goals and } \\
\text { objectives }\end{array}$ & .635 & .771 & \\
\hline & Our brand stay for the values of our organization & .566 & .782 & \\
\hline & Our marketing was guided by our brand values & .596 & .776 & \\
\hline & We strive for the Integration of our marketing activities & .579 & .779 & \\
\hline & $\begin{array}{l}\text { Our office layout, logo, and clothing present our } \\
\text { brand's values }\end{array}$ & .689 & .760 & \\
\hline & Cronbach's alpha: 0.809 & & & \\
\hline \multirow{6}{*}{ 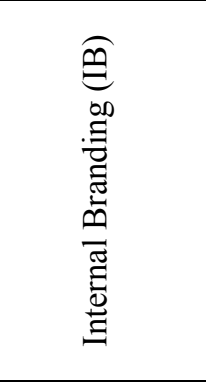 } & Our employees are informed of our brand values & .639 & .800 & \\
\hline & We regularly discuss branding in the company & .676 & .789 & \\
\hline & $\begin{array}{l}\begin{array}{l}\text { Brand values influence staffing and recruitment } \\
\text { decisions }\end{array} \\
\end{array}$ & .630 & .802 & \\
\hline & $\begin{array}{l}\text { We review our employers behavior as a part of our } \\
\text { branding process }\end{array}$ & .601 & .810 & \\
\hline & $\begin{array}{l}\text { We are confidence that our employees support the } \\
\text { brand messages when dealing with our customers. }\end{array}$ & .627 & .803 & \\
\hline & Cronbach's alpha: 0.834 & & & \\
\hline \multirow{5}{*}{ 总 } & We have reached desired image in the market & .349 & .636 & \\
\hline & Our firm has strong reputation & .393 & .613 & \\
\hline & Our firm has built a strong customer brand loyalty & .376 & .626 & \\
\hline & Our brand has a strong brand awareness in the market & .634 & .431 & \\
\hline & Cronbach's Alpha: 0.652 & & & \\
\hline \multirow{4}{*}{ 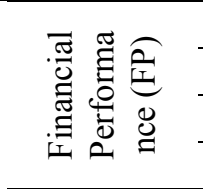 } & We satisfy with our ROA & .910 & .903 & \\
\hline & We satisfy with our ROE & .914 & .902 & \\
\hline & We satisfy with our sales growth & .915 & .902 & \\
\hline & Cronbach's Alpha: 0.940 & & & \\
\hline
\end{tabular}

Source: Survey's data 
The results of Reliability Analysis report that Cronbach's Alphas range from 0.652 to 0.904 which indicates moderate to high level of reliability for the 05 variables. However, some of the items should be deleted as shown in Table 2.

\section{Correlation and Regression Analysis}

\subsection{Correlation Analysis}

In order to determine the relationship between branding and performance, correlation analyses were used. This study intends to investigate how brand performance is influenced by brand orientation, brand identity development and internal branding, and how financial performance is influenced by brand performance. Therefore, BP is considered dependent variables in the correlation analyses with $\mathrm{BO}, \mathrm{BID}$, and IB, and is considered independent variable in the correlation analysis with FP.

Bivariate Correlation Analysis was performed by SPSS software to determine if significant relationships among the variables exist. All variables are of Ordinal data type, thus Spearman's rho correlations were applied. Table 3 shows how the 04 variables BO, BID, IB and FP correlate with BP.

Table 3. Results of Bivariate Correlation Analysis

\begin{tabular}{|c|c|c|c|c|c|}
\hline & rman's rho & Bo & BID & IB & FP \\
\hline \multirow{2}{*}{ BP } & Correlation Coefficient & $.188^{*}$ & $.386^{* *}$ & $.407^{* *}$ & $.320^{* *}$ \\
\hline & Sig. (2-tailed) & .029 & .000 & .000 & .000 \\
\hline
\end{tabular}

Correlation is significant at the 0.01 level (2-tailed)

* Correlation is significant at the 0.05 level (2-tailed).

All of the correlation coefficients are positive and statistically significant (at under .05 level). However, the correlation coefficients between the variables are quite low (under .41), especially that of BP and BO (under .20). These results indicate that there are positive relationships among the variables, but their strength of association is very weak (between BID and BP; between IB and BP, and between BP and FP) and even null (between BO and BP).

\subsection{Regression Analysis}

The multiple regression model was conducted to build a function of the relationship between 03 independent variables $\mathrm{BO}, \mathrm{BID}$ and IB and the dependent variable $\mathrm{BP}$. The proposed function is in the form of $\mathrm{BP}=\mathrm{a}+\mathrm{b} * \mathrm{BO}+$ $c^{*} \mathrm{BID}+\mathrm{d}^{*} \mathrm{IB}$.

Table 4. Results of Multiple Regression Analysis

\begin{tabular}{|c|c|c|c|c|}
\hline Dependent Variable - BP & $\mathbf{R 2}$ & Adjusted R2 & $\begin{array}{c}\text { Standardized } \\
\text { Coefficient } \\
\text { (beta) }\end{array}$ & Sig. \\
\hline BO & & & -.018 & .836 \\
\hline BID & .208 & .190 & .283 & .005 \\
\hline IB & & & .247 & .008 \\
\hline
\end{tabular}

$($ Constant $=6.623 ; \mathrm{p}=.000)$

The model is: $\mathrm{BP}=6.623-0.01 * \mathrm{BO}+0.283 * \mathrm{BID}+0.247 * \mathrm{IB}$ 


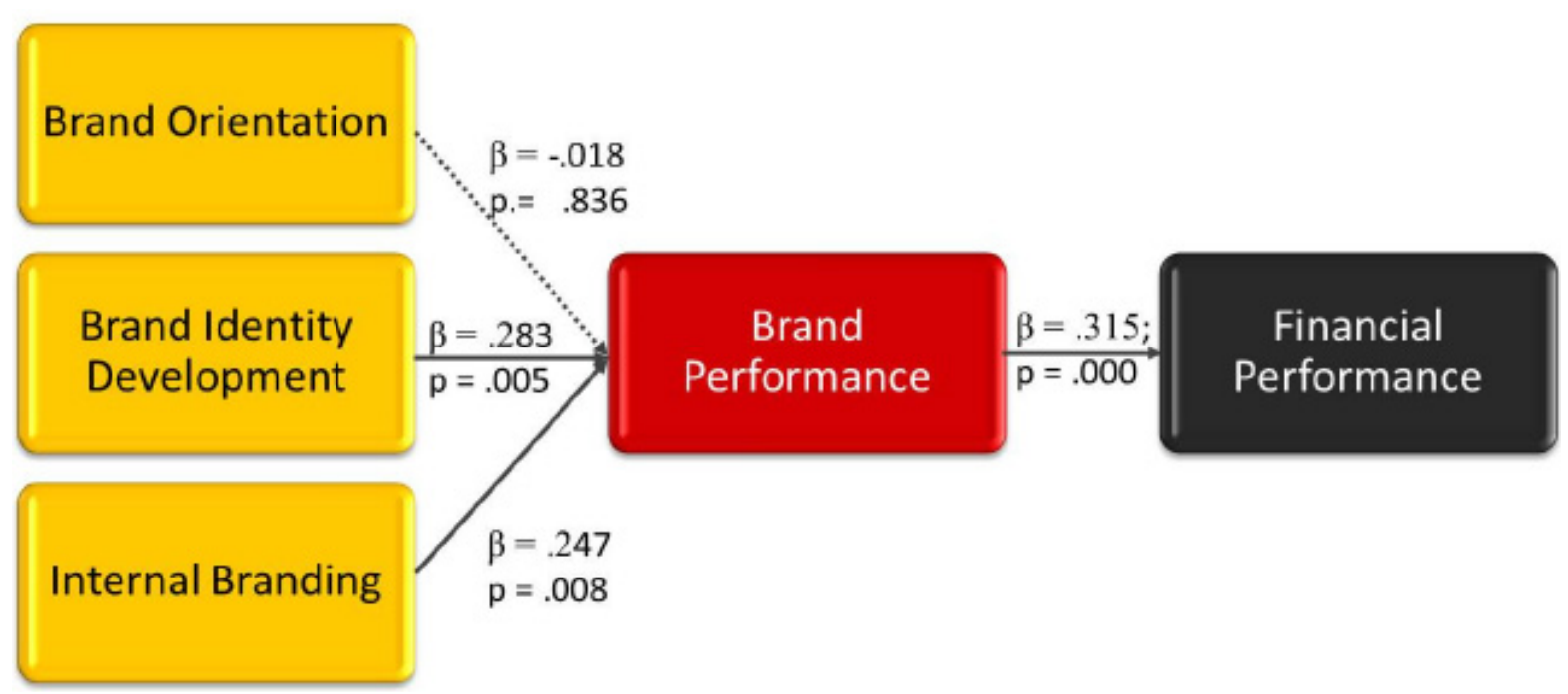

Figure 1. Model fitness using Multiple Regression Analysis

The results from multiple regression analysis shows that BID and IB have positive relationships with BP (Beta BID $=0.283, \mathrm{p}<0.01$; Beta IB $=0.247, \mathrm{p}<0.01)$. However, the relationship between $\mathrm{BO}$ and $\mathrm{BP}$ is negative (Beta $\mathrm{BO}=$ $-.018, \mathrm{p}>0.05$ ). Although the proposed function cannot be proven (due to high significance value of Beta $\mathrm{BO}$ ), the positive relationship between BID, IB and BP were reconfirmed. Consequently, the hypothesis H1 is rejected; H2, $\mathrm{H} 3$, and $\mathrm{H} 4$ are supported.

Table 5. Summary of the hypothesis' testing results

\begin{tabular}{|c|l|l|l|}
\hline Hypothesis & \multicolumn{1}{|c|}{ Descriptions } & Results \\
\hline H1 & Brand orientation is positively related to brand performance. & Rejected \\
\hline H2 & $\begin{array}{l}\text { Brand identity Development is positively related to brand } \\
\text { performance. }\end{array}$ & Supported \\
\hline H3 & Internal branding is positively related to brand performance. & Supported \\
\hline H4 & Better brand performance contributes to more satisfied financial & Supported \\
\hline
\end{tabular}

As seen in the above table, $\mathrm{H} 1$ is the only hypothesis that has been rejected due to the low correlation coefficient between brand orientation and brand performance. The other three hypotheses $\mathrm{H} 2, \mathrm{H} 3$ and $\mathrm{H} 4$ are approved.

\section{Findings and Discussions}

\subsection{Brand Orientation and Its Relationship with Brand Performance}

The collected data showed that the majority of the participating firms are in a high level of brand orientation. Firms are quite optimistic when answering the questions about brand orientation. The large number of the respondents strongly agrees with the issues (around $80 \%$ ). The mean values of all answers are the highest among all parts (all are above 4.0). The number of Absolutely Agree answers in Brand Orientation component is the highest comparing to other options and to those in other components, either. However, the variance among firms in the 05 issue is also the highest that reflect an inconsistency among firms about brand orientation. 
Also, the results show that hypothesis 1 cannot be approved. The result is not consistent with previous studies (by Wong and Merrilees, 2008; Tuominen et al., 2009; Anne et al, 2015). There are some reasons to explain for the unclear correlation between brand orientation and brand performance. Firstly, brand orientation includes various aspects inside, and brand oriented firms are required to take various actions in a long period of time. Consequently, there is a certain lag before their efforts have taken results. Secondly, the idea of brand oriented firms is quite new in Vietnam. As mentioned before, brand orientation is a mindset that ensures that the brand will be recognized, featured and favored in the marketing strategy. It would give direction of a firm in terms of strategic marketing planning. Thus, the SMEs brand orientation integrates both cultural and behavioral perspectives. Hankinson (2002) noted that "the prior belief in the brand supports the concrete behaviors." Meanwhile, Vietnamese firms' belief on branding which is in the infant stage may be not strong enough to support actions. Thirdly, branding is a large issue and many factors, both subjective and objective, may influence the results. The impact of brand orientation toward brand performance, therefore, may be rather small in comparison to that of other circumstanced factors, especially in the research context of Vietnamese F\&B industry at this moment when economic crisis has not yet over. As a result, the link between brand orientation and brand performance is not clear in this situation.

Therefore, further studies on this topic should be done to explore firm's perspectives on brand orientation and its impacts on firm's performance in Vietnam's.

\subsection{Brand Identity Development and Its Relationship with Brand Performance}

The research results show that most of the respondents considered their brand identity development are in moderate-to-high level. Especially, nearly one fourth of the firms show a very high level of brand identity development. The data indicates that firms' efforts are balanced on all aspects on brand identity development. Almost none of the firms stand outside of the branding process. No issues are neglected or omitted. The mean values of the items in this section are quite closed to each other, fluctuating in a small range (from 3.84 to 4.13 ). The variance is small enough. This reflects a similar level of brand identity focus in the company of respondents.

Results reveal that brand identity development has a positive and significant influence on brand performance, thus the hypothesis on the relationship between brand identity and brand performance within Vietnamese F\&B SMEs is approved ( $\mathrm{rS}=.386, \mathrm{p}=.000, \mathrm{R} 2=.163$ ). This result is similar to previous studies (Coleman, 2011; Kapferer, 2008; Aaker and Joachimsthaler, 2002; Anne et al, 2015).

\subsection{Internal Branding and Its Relationship with Brand Performance}

The data show that internal branding in Vietnamese $F \& B$ firms is of above moderate level. The mean values range from 3.42 to 4.18 , slightly lower than those in brand orientation and brand identity development sections. The majority of the respondents insist on the role of employee's behavior in firm's branding process $(82.22 \%)$. They are also quite confident that their employees are informed of their brand value $(79.25 \%)$, but one third of them are not confident that their employees are well in support the brand message while dealing with customers. Half of the respondents confirmed that branding topic is not frequently discussed, and brand values do not have much influence in staffing and recruitment decision. This fact contradicts to the results of brand orientation section in which firms' responses reveal that they are highly brand oriented.

The research result proves that there is a positive relationship between internal branding and brand performance $(\mathrm{rS}=.407, \mathrm{p}=.000, \mathrm{R} 2=.153)$. This research's finding is consistent with branding theory regarding the intangible asset value of internal brand communication. As explained in the literature review, "while branding initiatives most frequently focus on external stakeholders, internal marketing, employee branding and/or internal branding efforts establish systems/processes and consequent employee behaviors that are consistent with the external branding efforts". Huge benefits would be enjoyed from effective internal branding. Companies perform better with workforces that understand how they operate (Aurand et al., 2005; de Chernatony and Segal-Horn, 2003; Hirnoven \& Laukkanen 2011; Jagdish and Mona, 2015). Consequently, internal branding, if successfully implemented, would promote brand performance (Aurand et al., 2005).

\subsection{Brand Performance and Its Relationship with Financial Performance}

The collected data reveal that participating firms have a moderate level of brand performance. Only half of the respondents are satisfied with their branding results; and only one third of them are confident that they have reached desired image. Noticeably, two third agrees that they has strong reputation. The number of firms who are satisfied and not satisfied with their brand awareness and brand loyalty are approximately equal. The mean values of internal branding items range from 3.29 to 3.78 , the lowest comparing to those in the 03 previous sections, but the variance is the smallest (just from .431 to .667 ). 
The result of nonparametric correlation analysis shows that brand performance shares a positive relationship with firm's financial performance $(\mathrm{rS}=.320, \mathrm{p}=.000, \mathrm{R} 2=.100)$. This finding also confirms the assumption that brand performance contributes to the success of financial performance. This result is also in line with results of some previous researches about the impact of brand performance towards firm's financial performance (Kim et al, 2003; Abimbola \& Vallaster, 2007; Anne et al, 2015).

\section{Conclusions}

This study has focused on verifying the relationship between branding and financial performance in the context of food and beverage SMEs in Vietnam. The results show that brand identity, internal branding, brand performance and financial performance are related constructs. Brand identity and internal branding have positive effects on brand performance which in turn affects positively financial performance. The findings empirically confirm the hypothesis that branding has a positive and significant effect on financial performance. On the other hand, the relationship between brand orientation and brand performance should be questioned and investigated in further studies.

Besides, the research shows that before managers can build their brands, they need to understand what dimensions that make their brand building process performance. This research provides certain guidance on what generally constitutes branding (dimensions) and what activities (items) comprise those dimensions. The list of items and the activities help Vietnamese SMEs to build their brand comprehensively. The framework of this survey provides company's owners with a conceptual apparatus to delineate branding while the items provide brand managers with specific activities to implement. The cases of financially successful firms imply that managers should carefully orchestrate all dimensions of their internal and external branding to get best performance. Only when managers approach brand building holistically will they realize the construct's full benefits.

Also, this study provides new insights about the impact of branding on brand and financial performance. The research results reveals that branding, especially internal and external branding, contributes to brand performance, and in return brand performance contributes to the success of financial performance. However, in the research context, brand orientation is not predicting better brand performance. The effect of factors such as marketing budget, branding known-how, and communication tools on brand performance is unremarkable. The results also reveal that firms of high performance consider all aspects of branding equally. This implies that branding should be invested synchronously at all and every issues.

In general, this research contributes to the marketing literature in Vietnam in several ways: (1) it has explored the level of branding practice among F\&B SMEs in Vietnam, (2), it has verified the impact of the branding on financial performance, (3) it brings the context of SMEs into consideration, and (4) it provides Vietnamese managers some suggestions for better branding activities and performance.

Nevertheless, the study has its limitations relating to the constructs as well as research methodological issues. Due to the time and resources constraint, this research limited within management perspective. Only three issues of brand orientation, brand identity development and internal branding were selected to examine their positive and significant influence on brand performance in Vietnamese F\&B SMEs. Moreover, further researches in other sectors should be done before generalizing these findings to other contexts (market, sector, or countries). Another limitation is that the sample composed by only the SMEs in some cities and provinces in Vietnam. In addition, the firms were not randomly selected because the lack of access to total list of F\&B SMEs in Vietnam. Therefore, it would be worth to collect more samples from other areas within the country to provide empirical support for the instrument, as well as to support the generalizability of the findings.

Furthermore, it would be interesting to compare two or more industries to find out how they practice in different approaches and how strong is the power of relationship between branding and performance.

\section{References}

Aaker, D. A., \& Joachimsthaler, E. (2002). Brand Leadership. Simon and Schuster, UK Ltd., London.

Abimbola, T., \& Vallaster, C. (2007). Brand, organizational identity and reputation in SMEs: an overview. Qualitative Market Research: An International Journal, 10(4), Emerald Group Publishing, 342.

Ahonen, M. (2008). Branding - does it even exist among SMEs?. Proceedings of the 16th Nordic Conference on Small Business Research, May 21st-23rd 2008, Tallinn, Estonia.

Anne, H. J., Leea, G. W., \& Jason, F. K. (2015). Creative food clusters and rural development through place branding: Culinary tourism initiatives in Stratford and Muskoka, Ontario, Canada. Journal of Rural Studies, 39, 133-144. http://dx.doi.org/10.1016/j.jrurstud.2015.05.001 
Aurand, T., Gorchels, L., \& Bishop, T. (2005). Human resource management's role in internal branding: an opportunity for cross-functional brand message synergy. Journal of Product and Brand Management, 14(3), 163-169.

Coleman, D., de Chernatony, L., \& Christodoulides, G. (2011). B2B service brand identity: Scale development and validation. Industrial Marketing Management Journal, 40(2001), 1063-1071. http://dx.doi.org/10.1016/j.indmarman.2011.09.010

de Chernatony, L., \& Segal-Horn, S. (2003). The criteria for successful service brands. European Journal of Marketing, 37(7-8), 1095-1118. http://dx.doi.org/10.1108/03090560310477681

Ewing, M. T., \& Napoli, J. (2005). Developing and validating a multidimensional nonprofit brand orientation scale. Journal of Business Research, 58(6), 841-853. http://dx.doi.org/10.1016/j.jbusres.2003.09.012

Hankinson, P. (2001). Brand orientation in the charity sector: A framework for discussion and research. International Journal of Nonprofit and Voluntary Sector Marketing, 6(3), 231-242. http://dx.doi.org/10.1002/nvsm.149

Henkel, S., Tomczak, T., Heitmann, M., \& Herrmann, A. (2007). Managing brand consistent employee behavior: relevance and managerial control of behavioral branding. Journal of Product and Brand Management, 16(5), 310-320.

Hirnoven, S., \& Laukkanen, T. (2011). Branding in Small Firms: Are All SMEs Similar? Proceedings of the ANZMAC 2011 Conference, Australia.

Jagdish, N. S., \& Mona Sinha. (2015). B2B branding in emerging markets: A sustainability perspective. Industrial Marketing Management, 51, 79-88. http://dx.doi.org/10.1016/j.indmarman.2015.06.002

Juntunen, M., Saraniemi, S., Halttu, M., \& Tahtinen J. (2010). Corporate brand building in different stages of small business growth. Journal of Brand Management, 18(2), 115-133. http://dx.doi.org/10.1057/bm.2010.34

Keller, K. L. (2003). Strategic Brand Management - Building, Measuring, and Managing Brand Equity. Pearson Education Inc., Upper Saddle River.

Kim, H., Kim, W. G., \& An, J. A. (2003). The effect of consumer-based brand equity on firm's financial performance. The Journal of Consumer Marketing, 2003, 20, 4/5, ABI/INFORM Global, 335.

King, C., \& Grace, D. (2006). Exploring managers' perspectives of the impact of brand management strategies on employee roles within a service firm. Journal of Services Marketing, 20(6), 369-380.

Lukoma, V., \& Nguyen, T. K (2011). Brand recognition for long term business growth in developing countries. Gotland University, 1-3, 17.

Papasolomou, I., \& Vrontis, D. (2006). Building corporate branding through internal marketing: the case of the UK retail brand industry. Journal of Product \& Brand Management, 15(1), 37-47. http://dx.doi.org/10.1108/10610420610650864

Reid, M., Luxton, S., \& Mavondo, F. (2005). The relationship between integrated marketing communication, market orientation, and brand orientation. Journal of Advertising, 34(4), 11-23. http://dx.doi.org/10.1080/00913367.2005.10639210

Tuominen, S., Laukkanen, T., \& Reijonen, H. (2009). Market Orientation, Brand Orientation and Brand Performance in SMEs: Related Constructs?. ANZMAC 2009, University of Joensuu.

Wong, H. Y., \& Merrilees, B. (2008). The performance benefits of being brand-orientated. Journal of Product and Brand Management, 17(6), 372-383.

\section{Note}

Note 1. Author's calculation based on statistics by GSO 2015 and VCCI's 2015 Annual Report on Vietnamese Enterprises 